\title{
Richard Bernstein and the Challenges of a Broadened Pragmatism
}

Roberto Frega

\section{CpenEdition}

Journals

Electronic version

URL: http://journals.openedition.org/ejpap/838

DOI: $10.4000 /$ ejpap.838

ISSN: 2036-4091

Publisher

Associazione Pragma

Electronic reference

Roberto Frega, "Richard Bernstein and the Challenges of a Broadened Pragmatism », European Journal of Pragmatism and American Philosophy [Online], III-2 | 2011, Online since 29 December 2011 connection on 30 April 2019. URL : http://journals.openedition.org/ejpap/838 ; DOI : 10.4000/ ejpap.838

This text was automatically generated on 30 April 2019.

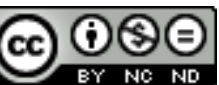

Author retains copyright and grants the European Journal of Pragmatism and American Philosophy right of first publication with the work simultaneously licensed under a Creative Commons AttributionNonCommercial-NoDerivatives 4.0 International License. 


\title{
Richard Bernstein and the Challenges of a Broadened Pragmatism
}

\author{
Roberto Frega
}

1 Richard Bernstein is among the pragmatist philosophers that have most significantly contributed to the advancement of a philosophical conversation between the American and the European traditions. His work has greatly helped the task of dismantling the boundaries that in the last decades had been erected between philosophical traditions. It is therefore with the greatest pleasure that The European Journal of Pragmatism and American Philosophy inaugurates his series of monographs with Bernstein's book The Pragmatic Turn. Bernstein's book is striking for his willingness to resist any temptation to appropriate pragmatism as being exclusively American. In reminding us of the commonalities among a wide range of philosophers engaged in a now successful pragmatic turn, Bernstein accomplishes a step forward in making pragmatism a living tradition, freed from any geographical specification or historical belonging. In opening this discussion about his last book, I will confine myself to some remarks concerning the way in which Bernstein conceives the relationships between the American pragmatist tradition and the wider pragmatic turn to which his book is devoted.

2 As the other great pragmatist thinkers of his generation, Richard Bernstein is a philosopher committed to an ecumenical task: to show that pragmatism is a living philosophical koiné. In order to do this he works incessantly at broadening its boundaries and at setting up philosophical conversations with other philosophical traditions. Each of the great figures of his generation has invented his own style for doing this. Richard Rorty has insistingly explored the affinities with Continental, and often literary and postmodern paths in philosophy. Joseph Margolis has offered philosophical frescoes of how the analytical, the continental and the pragmatist philosophies are conceptually entangled and historically dependent upon the same philosophical sources. Hilary Putnam has provided countless examples of how pragmatism could provide answers to 
problems set within the recent analytical tradition. Among these thinkers, Bernstein is the only one that has not started his career as an analytical philosopher, and his works has been pragmatic since its beginning. Yet, since at least his book Praxis and Action (1971), we find in Bernstein's work a never exhausted desire to set up new fronts of conversation. He has established and consolidate pragmatism through a host of conversational engagements: with Hannah Arendt, Hans-Georg Gadamer, Alasdair MacIntyre, Jacques Derrida, Jürgen Habermas and many others.

3 A central question that emerges through Bernstein's work, and especially in his last book, concerns inevitably the identity of the pragmatist tradition and its conceptual boundaries. In this perspective, what strikes me as paradoxical in Bernstein efforts - of course the fault is not his - is the apparent difficulty to seat pragmatism on its own foot. Through his conversation with the recent and somehow anomalous versions of "Kantian" and of "analytical" pragmatisms, Bernstein shows the tensions and the difficulties that seem to plague any effort at reclaiming the pragmatist tradition. This theme becomes compelling and explosive under Bernstein writing precisely because of his conversational openness and commitment to enlarge the pragmatist family. Bernstein takes his interlocutors extremely seriously, explores in depth their conceptual resources, tries to find all the possible lines of convergence between them and the pragmatist tradition. But at the end of the journey we are left with the feeling of irreconcilable distances. Any reader familiar with the pragmatist tradition cannot but share Bernstein's candid remark that "Brandom has a distorted view of the American pragmatists and his relation to them" (Bernstein 2010: 230) ${ }^{1}$ and that "Habermas's 'Kantian pragmatism' is an unstable stopping stage" (199), so that "one wishes that Habermas had been less 'Kantian' and more "pragmatic" (197). Similar if not stronger remarks could be made (and have been made) about the pragmatic character of Quine, Davidson, and McDowell philosophies. Yet the issue is timely and Bernstein's insistence at tackling with it has to be praised. The issue taken on by Bernstein, and the way he does it, are of the greatest importance not for mere parochial reasons concerning the disciplinary, academic boundaries of one's own philosophical garden.

What is involved in the philosophical conversations engaged by Bernstein is therefore the very possibility to establish pragmatism as a living contemporary tradition in philosophy. ${ }^{2}$ As all other authors that have striven with this issue, Bernstein knows that he is entrapped in a double bind: the more one stays close to the Classical tradition, the more pragmatism appears as a self-consistent but marginalized tradition. On the other side, the more one opens its boundaries, the more the pragmatist label becomes successful but the more it risks to lose its distinctiveness and philosophical significance. Accordingly, there are two main ways for dealing with the question of the pragmatist heritage: the first consists in insisting on the continuities between what is being called pragmatism today and the thought of the 'founding fathers': the Classical American pragmatists. Following this line of thought we are lead to ask ourselves what is the meaning of pragmatism, what its distinguishing traits, what its conceptual core, what the living actuality of the founding fathers. The second consists in acknowledging a wide convergence of different traditions on themes anticipated by the pragmatists but developed also by other philosophers. At a time where Pragmatism's Readers featuring contributions from Rudolph Carnap and Hans Reichenbach are being published, ${ }^{3}$ and where pragmatism is sometimes taken to refer to any conception that privileges pragmatic over semantic approaches to language, the question of the limits of conversation should be considered 
to be something more than a terminological quarrel over the right to use a label. In Bernstein's words, if "the expression 'pragmatism' is like an accordion" (11), then its meaning should be acknowledged to vary, even greatly, but nevertheless within limits. Here lies, in my opinion, the central question of the relationship between the 'pragmatist' and the 'pragmatic' that is at the heart of Bernstein's book.

Bernstein's strategy in tackling with this issue consists in insisting on the philosophical priority of the 'pragmatic' over the 'pragmatist.' He tells a narrative made out of a plurality of voices, all characterized by their allegiance to a pragmatic turn, of which pragmatism is merely one of the several components - although probably the most important. The pragmatic turn is characterized by the willingness to acknowledge a decisive explanatory function to social practices in epistemology and metaphysics. The pragmatic turn is therefore, more precisely, a practice turn. With respect to this wide family, the question remains open to determine what has been the specific contribution of pragmatism, say as against the wittgensteinian or the heideggerian. Bernstein's answer is mixed. He starts his book with three chapters on the classical pragmatists as if to recall the philosophical unity of this movement and its seminal function in giving rise to the pragmatic turn-the pragmatist core of the pragmatic turn. Yet in what follows the weight of the pragmatic 'sea change' is put nearly exclusively on Peirce's shoulders. Bernstein acknowledges Peirce's anti-Cartesianism as the founding moment of pragmatism. "Peirce opened up a new way of thinking that is still being pursued today in novel and exciting ways by all those who have taken the pragmatic turn" (52). What is, according to Bernstein, this "sea change" initiated by Peirce? Quite surprisingly, it is neither the introduction of the pragmatic maxim, nor the development of a theory of rationality as inquiry, nor his fallibilism. It is, rather, the fact of having found a via media between a dogmatic appeal to the given and an unacceptable frictionless coherentism. Defining pragmatism through this epistemological thesis is the strategic move that drives the rest of the book: it provides the starting point for a narrative of pragmatism aimed at emphasizing its analytical developments: Quine, Sellars, Davidson, Mc Dowell, Brandom, Habermas. Unsurprisingly, the unfolding of the book will leave quite unexplained the role played by the other pragmatists - Dewey, James, and Mead - in the accomplishing of the pragmatic turn: James contribution remains quite exclusively limited to the ethical, while Dewey's is focused on the political. The relevance of both authors in the succeeding chapters remains surprisingly modest.

6 This Peircean narrative proposed by Bernstein is certainly historically accurate, philosophically legitimate and strategically wise for a lot of reasons that the reader discovers while making his way through the book. Yet it puzzles me for at least two reasons. The first is that this narrative gives a very strong explanatory privilege to the role of language at the expenses of the role of social practices. It reduces the philosophical relevance of pragmatism to its contribution "in the way of words," as Bernstein himself likes to say using a sellarsian formula. The second is that, as I have recalled above, Bernstein seems to be the first to be unconvinced by this narrative, when he acknowledges Brandom's distorted view of pragmatism and Habermas' excessive Kantianism. Given the philosophical tastes of Bernstein, one would have expected him to deploy a more pluralistic narrative.

7 So here is the question I would like to address him: is not his account of pragmatism too much unbalanced towards these analytical and Kantian versions which have certainly a legitimate place at the borders of the pragmatist family but cannot be taken to define 
neither its historical nor its conceptual core? And secondly, if we accept to define pragmatism as an heterogeneous ensemble of thinkers united by family resemblances, don't he think that there still are some dominant, pervasive traits that could define the core of this philosophical tradition, and that cannot be limited to the Peircean move he sets at the start of his book? Or is he willing to drown pragmatism altogether within the pragmatic turn? A disingenuous reader might in fact be tempted to think that what Bernstein book teaches us is that pragmatism has contributed to philosophy either developing interesting theories that have no currency today or to adumbrating yesterday answers to questions that are being asked today at the cutting edge of philosophy. My question, in the end, amounts to ask whether according to him there is still a relevant sense in which we can speak of a pragmatist tradition alive today - and if yes how he would define its contours, or whether he thinks that it is enough to say that we should be content with acknowledging the existence of an extended pragmatic family, to which philosophers subscribe only on an individual basis.

8 I ask this question because I have the feeling that although the factual impossibility to provide a non controversial definition of pragmatism, I see powerful family resemblances within its members, and I have the feeling that by understating these resemblances we miss something important of the cultural and philosophical heritage of pragmatism. This heritage has to do with the peculiar way the pragmatist took social practices seriously. When the pragmatists 'discovered' the world of the social practices, what they had in mind where in fact historical processes, real communities, social factors, educational and transformational movements. Their appeal to social practices was much more radical than most of the 'practice' talk or of the 'social' talk that characterizes the philosophers that Bernstein addresses through his conversations. In a significantly different way, since the 'way of words' has taken on the philosophical scene, the social has been reduced to the inter-subjective, and practices have been reduced to discourses. Similarly, as Bernstein himself acknowledges, the present philosophical culture is exposed to idealistic temptations that impoverish our understanding of human experience. And I wonder whether the pragmatic philosophies of Quine, Sellars, Davidson, McDowell, Brandom and Habermas - their fundamental philosophical importance notwithstanding - really help us in vindicating the philosophical importance of the social practices; whether, in other words, they really support us in making philosophical sense of experience after the linguistic turn or whether they are not simply pursuing a different philosophical project. The philosophical tension between language and experience is part of our philosophical culture, and as such it traverses all Bernstein's book and remains unresolved. This is probably the sign that, as Ramon del Castillo concludes in his contribution to this symposia, the pragmatic turn is still, at least partially, a task still before us. A task to which, nevertheless, Bernstein's book help us to come closer.

\section{NOTES}

1. Where not specified otherwise, all citations are from Bernstein's The Pragmatic Century, Polity Press, Cambridge, 2010. 
2. On this point see O'Shea's penetrating comments in his contribution to this symposia.

3. R. Talisse \& F. Aikin (eds.), The Pragmatism Reader: From Peirce through the Present, Princeton University Press, Princeton, 2011.

\section{AUTHOR}

\section{ROBERTO FREGA}

CNRS-IMM, Paris

fregarob[at]gmail.com 